\title{
LEGAL PROTECTION OF CUSTOMERS WHO MAKE PAYMENT THROUGH BRILINK E-BANKING (STUDY AT THE TANJUNG KARANG BRANCH OF BANK RAKYAT INDONESIA)
}

\author{
Angra Adinda Larakasih, Erlina B, Yulia Hesti \\ Bandar Lampung University \\ email: Angraadinda123@gmail.com, erlina@gmail.com, hyulia@gmail.com
}

\begin{abstract}
The development of technology is currently growing rapidly. This can be proven by advances in technology around the world. Technological progress is very important and has a very big effect on humans. Because technology is one of the supporting advances in human life. It can be proven that with the sophisticated technology, everything becomes fast and easy. The development of technological systems encourages the emergence of business opportunities in the internet field. In today's technology development it also influences the banking world. In conducting banking transactions through BRI Link agents, customers also receive protection for their rights to receive compensation for losses they have suffered. Customers as consumers of products and I or services offered by banks as producers are entitled to compensation for losses they experience when making transactions with e-banking facilities or services. Banks are required to provide compensation to customers as consumers of banking services for losses from using e-banking provided by the bank. However, it should be noted that this provision does not apply if the customer suffers a loss due to the previous customer's actions or negligence. Then the bank will solve it because the settlement of customer complaints is a form of increasing customer protection in order to guarantee customer rights in dealing with the bank.
\end{abstract}

Keywords: legal protection; customer; e-banking

\section{Introduction}

The development of technology is currently growing rapidly. This can be proven by advances in technology around the world. Technological progress is very important and has a very big effect on humans. Because technology is one of the supporting advances in human life. It can be proven that with the sophisticated technology, everything becomes fast and easy. The development 
Angra Adinda Larakasih, Erlina B, Yulia Hesti LEGAL PROTECTION OF CUSTOMERS WHO MAKE PAYMENT THROUGH BRILINK E-BANKING (STUDY AT THE TANJUNG KARANG BRANCH OF BANK RAKYAT INDONESIA)

of technological systems encourages the emergence of business opportunities in the internet field. In today's technology development it also influences the banking world.

Indonesian Banking Law is a law that regulates banking problems currently in effect in Indonesia. Thus, it means discussing banking rules that are still in effect today, while banking regulations that have been in effect in the past are only discussed if they are related to current regulations or discussions within the framework of banking history in Indonesia (Djumhana, 2000).

Act Number 7 of 1992 concerning Banking explains that banking is everything that is related to a bank, including institutions, business activities, and methods and processes of carrying out its business activities. Banking has a very important role in the economy in Indonesia. Over time, banking institutions have progressed. One of the applications of information technology in banking is the emergence of e-banking services or internet banking using internet banking, banks will be facilitated to improve customer service because internet banking services provided by banks can simplify everything. Besides making it easier for banks and customers, internet banking also has its own risks.

Internet banking is one of the banking transaction technologies offered by commercial banks in Indonesia for customers to make transactions such as transfers, payments, etc., easily and quickly.

Internet Banking is now no stranger to Indonesian society, for example with the emergence of BRI Link. In 2012 the Government and Bank Indonesia have prepared the launch of Branchless Banking or banking services without relying on branch offices and using technology to reach their customers (Evi Yani, Ade Fitria Lestari, Hilda Amalia, 2018). Following up on this matter in 2015, the Financial Services Authority (OJK), hereinafter referred to as (OJK), became the authority in banking and financial institution supervision. Article 34 of Act Number 3 of 2004 concerning Amendments to Act Number 23 of 1999 concerning Bank Indonesia is the basis for the formation of the OJK in Indonesia as an independent financial services sector supervisory institution. Based on their authority,

Then launched the LAKU PANDAI (Officeless Financial Services in the Framework of Inclusive Finance) program. Bank Rakyat Indonesia (Persero) Tbk then followed up this service by launching the BRI Link Program.

This is of course very profitable for BRI because BRI has customers all over Indonesia to remote areas of the country. Therefore, with the BRI Link, BRI can reach its customers who are in remote areas, without having to build an office in that area. These individuals who serve the BRI Link business are known as BRI Link Agents. However, the problem that often occurs when using BRILink is that if transfers to other banks often experience disruption. In conducting 
Angra Adinda Larakasih, Erlina B, Yulia Hesti LEGAL PROTECTION OF CUSTOMERS WHO MAKE PAYMENT THROUGH BRILINK E-BANKING (STUDY AT THE TANJUNG KARANG BRANCH OF BANK RAKYAT INDONESIA)

banking transactions through BRI Link agents, customers also receive protection for their rights to receive compensation for losses they have suffered.

This is in accordance with Article 22 letter f POJK No. 19 / POJK.03 / 2014 which states that, "The managing bank is obliged to be responsible for customer losses arising from the actions and actions of the agent which are included in the scope of agent services as stated in the cooperation agreement".

Based on the background description above, the authors are interested in conducting research as outlined in the form of a proposal with the title: "Law on Protection of Customers Who Make Payments Through E-Banking BRILink (Study at Bank Rakyat Indonesia)".

\section{Methods}

The problem in this research is through a normative juridical approach in order to obtain a correct and objective research result. The normative juridical research approach is an approach by examining the principles, norms, rules related to the problem to be studied.

In this study, the authors used data collection techniques based on juridical analysis methods by collecting information / data through library research (library research). Research library (library research), namely research conducted to obtain secondary data related to the author's research.

The data used in this study include secondary data, namely: data obtained from the library literature study. This data is obtained by studying, reading, citing and analyzing the related literature, principles and theories of law and regulations related to the subject of this research. Furthermore, secondary data in this study consisted of three (3) legal materials:

1) Primary Legal Materials

a. Book of Civil Law Book III concerning Engagement

b. Act Number 10 of 1998 concerning Amendments to Law Number 7 of 1992 concerning Banking.

c. Law Number 8 of 1999 concerning Consumer Protection.

d. Law Number 37 Year 2004 concerning Bankruptcy and Postponement of Debt Payment Obligations.

e. Law Number 11 of 2008 concerning Electronic Information and Transactions.

f. Decree of the Minister of Industry and Trade of the Republic of Indonesia Number 350 / MPP / Kep / 12/2001 concerning Implementation of Duties and Authorities of Consumer Dispute Resolution Bodies.

g. Financial Services Authority Regulation Number 1 / POJK.07 / 2013 concerning Consumer Protection in the Financial Services Sector. 
Angra Adinda Larakasih, Erlina B, Yulia Hesti LEGAL PROTECTION OF CUSTOMERS WHO MAKE PAYMENT THROUGH BRILINK E-BANKING (STUDY AT THE TANJUNG KARANG BRANCH OF BANK RAKYAT INDONESIA)

h. Financial Services Authority Regulation Number 1 / POJK.07 / 2104 concerning Alternative Institutions for Dispute Resolution in the Financial Services Sector.

i. Financial Services Authority Regulation Number 38 /POJK.03/2016 concerning Application of Risk Management in the Use of Information Technology by Commercial Banks.

j. Bank Indonesia Regulation Number 10/10 / PBI / 2008 concerning Amendments to Bank Indonesia Regulation Number 7/7 / PBI / 2005 concerning Resolution of Customer Complaints.

k. Bank Indonesia Regulation Number 14/2 / PBI / 2012 concerning Amendments to Bank Indonesia Regulation Number 11/11 / PBI / 2009 concerning Implementation of Card-Based Payment Instrument Activities.

1. Bank Indonesia Regulation Number 16/1 / PBI / 2014 concerning Consumer Protection for Payment System Services.

m. Indonesian Banking Dispute Resolution Alternative Institution Regulation Number 07 / LAPSPI-PER / 2015 concerning Mediation Rules and Procedures.

n. Indonesian Banking Dispute Resolution Agency Regulation Number 08 / LAPSPI-PER / 2015 concerning Rules and Procedures for Adjudication.

o. Indonesian Banking Dispute Resolution Alternative Institution Regulation Number 09 / LAPSPI-PER / 2015 concerning Arbitration Rules and Procedures.

2) Tertiary Legal Materials

The supporting materials for this research were obtained from the internet / website, scientific writings related to research.

\section{Result and Discussion}

\section{Discussion}

Legal protection for customers who make payments via BRI Link E-Banking at the tanjung Karang branch of the BRI Bank

The data on the implementation of legal protection for internet banking customers at the Tanjung Karang branch of the Indonesian people's bank that the researchers obtained are as follows, as a unit or sub-branch office (KCP), the Tanjung Karang unit serves internet banking facilities individually which are directly offered and explained by customer service (CS). How to get internet banking facilities for Indonesian people's banks through procedures. The first procedure for obtaining internet banking facilities is to fill in a stamped statement that is really using this internet banking facility. In banking services concerning internet banking, as a customer service they must explain the advantages and disadvantages of internet banking so that the customers who 
Angra Adinda Larakasih, Erlina B, Yulia Hesti LEGAL PROTECTION OF CUSTOMERS WHO MAKE PAYMENT THROUGH BRILINK E-BANKING (STUDY AT THE TANJUNG KARANG BRANCH OF BANK RAKYAT INDONESIA)

use them know all the consequences. There are many ways to access internet banking, but most customers use it via Bank Rakyat Indonesia (BRI) Mobile. BRI Mobile is already available on the play store or a place to download the current era android mobile application. When a customer has registered for internet banking, they will be given a user id which is a series of letters which is an identification to enter and access their internet banking account also equipped with a password.

The complaint as the main weakness that customers often experience in using internet banking at the Tanjung Karang branch here is that customers who use internet banking facilities forget their user id or password. For customer negligence such as forgetting user id and password, it is beyond the responsibility of the bank, but the bank will help resolve it quickly if the customer immediately reports to the customer service. The problem of forgetting internet banking user id and password customer service can help repair by checking customer data through savings books, automated teller machines (ATMs), and customer identity cards (KTP). Such disturbances should be avoided by memorizing and keeping their user id and password secret. The second weakness in internet banking is the network problem usually caused by internet banking customers. Network problems have a separate team to solve them in the fastest possible time, usually a maximum of three (3) days.

Steps to avoid hackers or crackers, namely other people who are not entitled to enter a customer's internet banking account, one of which is to change the password regularly. The procedure for changing the password includes:

a. The customer visits the nearest BRI office to get a user id and create a new password.

b. Registration, in order to re-register, previously registered services must be deleted, the condition is to show the original KTP, savings book or ATM card.

c. These steps can be taken by customers using the BRI internet banking facility which functions to prevent forgetting or being alert to hackers.

For protection from the Indonesian people's bank, all units are generally the same as in the center. The provisions concerning the written policies and procedures of the bank providing legal protection are stipulated in Bank Indonesia circular letter (SEBI) No. 7/7 / PBI / 2005 concerning Resolution of Consumer Complaints as amended by Bank Indonesia Regulation No. 10/10 / PBI / 2008 ("PBI No. 7/2005, among others, are as follows:

a. The bank's obligation to resolve complaints includes the obligation to resolve complaints submitted orally and or in writing by customers or customer representatives, including those submitted by an institution, legal entity, or other bank that is a customer of the bank. 
Angra Adinda Larakasih, Erlina B, Yulia Hesti LEGAL PROTECTION OF CUSTOMERS WHO MAKE PAYMENT THROUGH BRILINK E-BANKING (STUDY AT THE TANJUNG KARANG BRANCH OF BANK RAKYAT INDONESIA)

b. Every customer has the right to file a complaint.

c. Complaints can be filed by customer representatives acting for or on behalf of customers based on a special power of attorney from the customer.

Legal protection for internet banking customers under other names, in the banking sector, the provisions that provide legal protection for bank customers as or equal to consumers include the introduction of the Deposit Insurance Corporation (LPS) in Law number 10 of 1998, namely as a legal entity. which carries out insurance activities for deposits of depositing customers, through insurance schemes, buffer funds, and others. At the technical level, the legal umbrella that protects customers includes regulations regarding the resolution of customer complaints and banking mediation in the regulations of Bank Indonesia (PBI), including in the Tanjung Karang branch of the Indonesian people's bank (BRI).

\section{Preventive Legal Protection}

In the Financial Services Authority Regulation Number 1 / POJK.07 / 2013 concerning Consumer Protection in the Financial Services Sector, namely in Article 25, Article 27, Article 29, it is stated about the obligations of Financial Services Business Actors, namely: Article 25: "Financial Service Businesses are obliged to maintain security. savings, funds, or consumer assets that are under the responsibility of the Financial Service Businesses ".

Article 27: "Financial Service Providers are required to provide reports to Consumers regarding the position of balances and movements of consumer deposits, funds, assets, or liabilities accurately, on time, and by means or means in accordance with the agreement with the Consumers".

Article 29: "Financial Services Business Actors are obliged to be responsible for consumer losses arising from errors and / or negligence, management, employees of Financial Service Business Actors and / or third parties working for the benefit of the Financial Service Business Actors".

Article 23 of the Financial Services Authority Regulation Number 38 /POJK.03/2016 concerning the Implementation of Risk Management in the Use of Information Technology by Commercial Banks states that:

(1) Banks are required to carry out Information Technology-Based Transaction Processing in the territory of Indonesia.

(2) Information Technology-based Transaction processing can be performed by service providers in the territory of Indonesia.

(3) The operation of Information Technology-Based Transaction Processing by service providers as referred to in paragraph (2) may be carried out as long as:

a. Fulfilling the precautionary principle;

b. Fulfills the requirements as referred to in Article 20 paragraph (3), paragraph (4), and paragraph (5); and 
Angra Adinda Larakasih, Erlina B, Yulia Hesti LEGAL PROTECTION OF CUSTOMERS WHO MAKE PAYMENT THROUGH BRILINK E-BANKING (STUDY AT THE TANJUNG KARANG BRANCH OF BANK RAKYAT INDONESIA)

c. Pay attention to aspects of customer protection.

(4) Information Technology-based Transaction processing by Information Technology service providers can be carried out outside the territory of Indonesia as long as:

a. Fulfill the requirements as intended in paragraph (3);

b. Supporting documents for financial administration for transactions conducted at a Bank office in Indonesia must be administered at a Bank office in Indonesia;

c. The Bank's business plan shows an effort

(5) to enhance the role of the Bank in the development of the Indonesian economy;

Obtaining prior approval by the Financial Services Authority. Then inside

Article 29 states that: "Banks are required to apply the principle of controlling customer data security and Electronic Banking Service transactions in every Electronic System used by Banks".

Article 27 paragraph (1) of Bank Indonesia Regulation Number 16/1 / PBI / 2014 concerning Consumer Protection for Payment System Services states that providers are required to provide information regarding the benefits, risks, and consequences for Consumers for using Payment System services.

Current advances in science and technology increase the likelihood of financial losses experienced by customers. Law Number 8 of 1999 concerning Consumer Protection, namely Article 4 letter a, clearly states that consumers have the right to comfort, security and safety in consuming goods and / or services. In addition, Article 29 paragraph (4) of Law Number 10 of 1998 concerning Amendments to Law Number 7 of 1992 concerning Banking also states, for the benefit of customers, banks provide information regarding the possible risk of loss for customer transactions conducted through banks. .

In the context of consumer protection, Law Number 11 of 2008 concerning Electronic Information and Transactions regulates the existence of neutral technology used in electronic transactions, and requires an agreement on the use of electronic systems to be used.41 Apart from that in the provisions of Article 15 of Law Number 11 of Year In 2008 regarding Electronic Information and Transactions, it is stated that every electronic system operator is required to provide an electronic system that is reliable and safe and is responsible for the proper operation of the electronic system. The electronic system operator is responsible for the operation of the electronic system.

However, this provision does not apply in the event that it can be proven that there is a state of force, error, and / or negligence on the part of the electronic system user. 
Angra Adinda Larakasih, Erlina B, Yulia Hesti LEGAL PROTECTION OF CUSTOMERS WHO MAKE PAYMENT THROUGH BRILINK E-BANKING (STUDY AT THE TANJUNG KARANG BRANCH OF BANK RAKYAT INDONESIA)

\section{Repressive Legal Protection}

The problems between banks and customers are more about civil problems and the resulting losses are also financial losses so that to solve them, there needs to be a guarantee of compensation for losses suffered by the customer. In the provisions of Article 4 letter h of Law Number 8 Year 1999 concerning Consumer Protection, it is stated that consumers have the right to get compensation, compensation and / or replacement, if the goods and / or services received are not in accordance with the agreement or not as they should be. Therefore, a Customer as a consumer of products and / or services offered by a bank as a producer is entitled to compensation for losses suffered when making transactions with e-banking facilities or services. Banks are required to provide compensation to customers as consumers of banking services for losses from using e-banking provided by the bank. However, it should be noted that this provision does not apply if the customer suffers a loss due to the actions or negligence of the previous customer

\section{Settlement of Disputes in Payment via BRI E-Banking Link at the BRI Central Bank Office Tanjung Karang}

If a customer is disadvantaged in using e-banking, the first thing the customer must do is report it to the bank. Then the bank will solve it because the settlement of customer complaints is a form of increasing customer protection in order to guarantee customer rights in dealing with the bank. Customer complaints that are not immediately acted upon have the potential to increase reputation risk for banks and in the long run could reduce public confidence in banking institutions. Each bank itself is required to have a unit and or function that is specially established in each bank office to handle and resolve complaints submitted by customers and / or customer representatives. Number 8 of 1999 concerning Consumer Protection Jo. Decree of the Minister of Industry and Trade of the Republic of Indonesia Number 350 / MPP / Kep / 12/2001 concerning Implementation of Duties and Authorities of Consumer Dispute Resolution Bodies, Bank Indonesia Regulation Number 10/10 / PBI / 2008 concerning Amendments to Bank Indonesia Regulation Number 7/7 / PBI / 2005 concerning Customer Complaint Resolution and Financial Services Authority Regulation Number 1 / POJK.07 / 2013 concerning Consumer Protection in the Financial Services Sector. However, now there is a Financial Services Authority Regulation Number 1 / POJK.07 / 2104 concerning Alternative Institutions for Dispute Resolution in the Financial Services Sector. This OJK regulation is the basis for the establishment of an Alternative Dispute Resolution Institution in the Financial Services Sector. Then for the banking sector there is an Alternative Institute for Indonesian Banking Dispute Resolution. Its establishment 
Angra Adinda Larakasih, Erlina B, Yulia Hesti LEGAL PROTECTION OF CUSTOMERS WHO MAKE PAYMENT THROUGH BRILINK E-BANKING (STUDY AT THE TANJUNG KARANG BRANCH OF BANK RAKYAT INDONESIA)

The Alternative Institute for Indonesian Banking Dispute Resolution is an obligation. The Indonesian Banking Dispute Resolution Alternative Institute or commonly abbreviated as LAPSPI was formed by the banking sector association and registered with the OJK. LAPSPI itself provides three dispute resolution services, namely mediation, adjudication and arbitration. With LAPSPI operating since January 2016

The handling of complaints received through the Financial Customer Care (FCC) of the OJK is limited to verification and clarification.

Can be processed through the Internal Dispute Resolution (IDR) of Financial Services Business Actors (PUJK). The Press Release also contains the opinion of OJK Board of Commissioners Member for Consumer Education and Protection, Kusumaningtuti S Setiono, that the implementation of IDR is the implementation of POJK No. 1/2013 concerning Consumer Protection in the Financial Services Sector and PUJK responds by establishing a complaint unit and / or function service level agreement so that consumers feel well protected..

\section{Conclusion}

Legal protection for customers in e-banking transactions can be divided into two, namely preventive and repressive legal protection. The preventive legal protection provided to customers aims to prevent losses before the occurrence of an ebanking transaction, preventive legal protection has not been specifically regulated but can relate it to various regulations that determine the obligations of financial services business actors, which in this case are banks, such as the Financial Services Authority Regulation Number 1 / POJK.07 / 2013 concerning Consumer Protection in the Financial Services Sector, Bank Indonesia Regulation Number 16/1 / PBI / 2014 concerning Consumer Protection for Payment System Services, Law Number 8 of 1999 concerning Consumer Protection. All these legal regulations partially provide preventive legal protection for customers in conducting ebanking transactions. Then the preventive legal protection regulates the Customer as a consumer of products and / or services offered by the bank as a producer is entitled to compensation for losses experienced when making transactions with e-banking facilities or services. Banks are required to provide compensation to customers as consumers of banking services for losses from using e-banking provided by the bank. However, it should be noted that this provision does not apply if the customer suffers a loss due to the actions or negligence of the customer who has previously been warned or educated by the bank. Then the preventive legal protection regulates the Customer as a consumer of products and / or services offered by the bank as a producer is entitled to compensation for losses experienced when making transactions with e-banking facilities or services. Banks are required to provide compensation to customers as consumers of 
Angra Adinda Larakasih, Erlina B, Yulia Hesti LEGAL PROTECTION OF CUSTOMERS WHO MAKE PAYMENT THROUGH BRILINK E-BANKING (STUDY AT THE TANJUNG KARANG BRANCH OF BANK RAKYAT INDONESIA)

banking services for losses from using e-banking provided by the bank. However, it should be noted that this provision does not apply if the customer suffers a loss due to the actions or negligence of the customer who has been warned or educated by the bank. Then the preventive legal protection regulates the Customer as a consumer of products and / or services offered by the bank as a producer is entitled to compensation for losses experienced when making transactions with e-banking facilities or services. Banks are required to provide compensation to customers as consumers of banking services for losses from using e-banking provided by the bank. However, it should be noted that this provision does not apply if the customer suffers a loss due to the actions or negligence of the customer who has been warned or educated by the bank. Banks are required to provide compensation to customers as consumers of banking services for losses from using e-banking provided by the bank. However, it should be noted that this provision does not apply if the customer suffers a loss due to the actions or negligence of the customer who has previously been warned or educated by the bank. Banks are required to provide compensation to customers as consumers of banking services for losses from using e-banking provided by the bank. However, it should be noted that this provision does not apply if the customer suffers a loss due to the actions or negligence of the customer who has been warned or educated by the bank.

Regarding dispute resolution Settlement of problems between customers can be done by way of negotiation and currently there is an Indonesian Banking Dispute Resolution Institute (LAPSPI) which has settlement services in the form of mediation, adjudication and arbitration. However, if the alternative dispute resolution fails, the Bank still reports it to the OJK and the Court is the last option.

\section{Bibliografi}

Djumhana, M. (2000). Banking Law in Indonesia. PT. Citra Aditya Bakti.

Evi Yani, Ade Fitria Lestari, Hilda Amalia, A. P. (2018). The Influence of Internet Banking on Customer Interest in Transactions with the Technology Acceptance Model. Journal of Informatics, 5(1).

Book of Civil Law Book III concerning Engagement

Act Number 10 of 1998 concerning Amendments to Law Number 7 of 1992 concerning Banking.

Law Number 8 of 1999 concerning Consumer Protection.

Law Number 37 of 2004 concerning Bankruptcy and Postponement of Debt Payment Obligations.

Law Number 11 of 2008 concerning Electronic Information and Transactions.

Decree of the Minister of Industry and Trade of the Republic of Indonesia Number 350

/ MPP / Kep / 12/2001 concerning Implementation of Duties and Authorities of Consumer Dispute Resolution Bodies. 
Angra Adinda Larakasih, Erlina B, Yulia Hesti LEGAL PROTECTION OF CUSTOMERS WHO MAKE PAYMENT THROUGH BRILINK E-BANKING (STUDY AT THE TANJUNG KARANG BRANCH OF BANK RAKYAT INDONESIA)

Financial Services Authority Regulation Number 1 / POJK.07 / 2013 concerning Consumer Protection in the Financial Services Sector.

Financial Services Authority Regulation Number 1 / POJK.07 / 2104 concerning Alternative Institutions for Dispute Resolution in the Financial Services Sector.

Financial Services Authority Regulation Number 38 /POJK.03/2016 concerning Application of Risk Management in the Use of Information Technology by Commercial Banks.

Bank Indonesia Regulation Number 10/10 / PBI / 2008 concerning Amendments to Bank Indonesia Regulation Number 7/7 / PBI / 2005 concerning Resolution of Customer Complaints.

Bank Indonesia Regulation Number 14/2 / PBI / 2012 concerning Amendments to Bank Indonesia Regulation Number 11/11 / PBI / 2009 concerning Implementation of Card-Based Payment Instrument Activities.

Bank Indonesia Regulation Number 16/1 / PBI / 2014 concerning Consumer Protection for Payment System Services.

Indonesian Banking Dispute Resolution Alternative Institution Regulation Number 07 / LAPSPI-PER / 2015 concerning Mediation Rules and Procedures.

Indonesian Banking Dispute Resolution Agency Regulation Number 08 / LAPSPI-PER / 2015 concerning Rules and Procedures for Adjudication.

Indonesian Banking Dispute Resolution Agency Regulation Number 09 / LAPSPI-PER / 2015 concerning Arbitration Rules and Procedures. 